\title{
The Vitamin D Deficiency Pandemic: a Forgotten Hormone Important for Health
}

\author{
Michael F. Holick, PhD, MD
}

\begin{abstract}
Early in the twentieth century more than 80 percent of children in industrialized Europe and North America were ravaged by the devastating skeletal consequences of rickets. Finding that exposure to ultraviolet radiation or sunlight treated and prevented rickets led to the ultraviolet irradiation of foods including milk. These practices along with the fortification of a variety of foods including dairy products with vitamin $\mathrm{D}$ and widespread use of cod liver oil eradicated rickets as a significant health problem by the late 1930s. Many countries mandated the fortification of milk with vitamin D to prevent rickets during wartime shortages. In the 1950s, in Europe, many countries forbid fortification of dairy and food products except breakfast cereals and margarine because of an outbreak of vitamin D intoxication in neonates.

Vitamin D deficiency has again become a major public health interest with its association with osteoporosis, osteomalacia, fractures, and more recently with prevention of cancer, diabetes, heart disease and other chronic illnesses. Regular sun exposure has decreased due to changing lifestyles. Vitamin D deficiency is especially prevalent in dark skinned children and adults living in Northern latitudes, and obese children and adults. Improving the vitamin D status worldwide would have dramatic effects on public health, and reduce healthcare costs for many chronic diseases. The most cost-effective way to remedy this deficiency is to increase food fortification with higher levels of vitamin D along with sensible sun exposure, and adequate vitamin D supplementation. I review the pathophysiology of vitamin D deficiency and its health consequences and provide recommendations for a new policy approach to this vital public health issue.
\end{abstract}

Key Words: vitamin D deficiency, micronutrient deficiency conditions, pandemic, global health, 25-hydroxyvitamin D, osteoporosis, rickets

\footnotetext{
${ }^{1}$ Department of Medicine, Section of Endocrinology, Nutrition, and Diabetes. Vitamin D, Skin and Bone Research Laboratory, Boston University Medical Center, Boston University School of Medicine, 85 East Newton Street, M-1013 Boston, MA, USA.
}

Correspondence: Michael Holick at email mfholick@bu.edu 


\section{INTRODUCTION: HISTORICAL PERSPECTIVE}

At the early part of the $20^{\text {th }}$ century, rickets remained one of the most devastating health consequences of the Industrial Revolution. ${ }^{1,2}$ It was estimated that more than 90 percent of children in Northern Europe and 80 percent of children in Boston and New York City showed evidence of this bone deforming disease. As early as 1822 Sniadecki identified the importance of sun exposure for preventing growth retardation and skeletal deformities associated with rickets noting that children living in the inner city of Warsaw had a high incidence of rickets whereas children living in adjacent rural areas did not. ${ }^{3}$ This was followed by the insightful observations in 1889 by Palm that children living in London and Glasgow were plagued with rickets while children who lived in squalor in Asia and India were free of the disease. ${ }^{1} \mathrm{He}$ recommended that children from the inner cities should be exposed to sunlight and encouraged sunbathing as a preventive and treatment strategy. However, the medical community found it inconceivable that skin exposure to sunlight could have any beneficial effect for bone health. In 1919, Huldschinsky exposed children to a mercury arc lamp and demonstrated radiologic healing of rickets. ${ }^{4} \mathrm{He}$ promoted the use of ultraviolet irradiation as an infallible cure for rickets. Pharmacies in the United States and Europe sold ultraviolet lamps to parents so that they could expose their children to the anthracitic ultraviolet radiation. In 1921, Hess and Unger exposed several children who had rickets to sunlight on the roof of a New York City hospital and demonstrated dramatic improvement in their rickets. ${ }^{1}$

Common folklore, especially in Scandinavian countries and on the coastline of Great Britain, had known that cod liver oil was effective in preventing and treating rickets. Studies conducted on rachitic rodents demonstrated that when they were irradiated with an ultraviolet lamp, the healing of rickets was similar to that of rachitic rodents that received cod liver oil, suggesting that the antirachitic factor was both a nutrient and a hormone. These observations prompted Steenbock to introduce the concept of irradiation of people and animals to induce antirachitic activity, and to then suggest the irradiation of food. He and his colleagues demonstrated that irradiating a wide variety of foods with ultraviolet radiation imparted antirachitic activity. This led them to irradiate milk with ultraviolet radiation as a simple way to prevent rickets in children. The practice of using ultraviolet radiation of milk was quickly implemented throughout the US, Canada and Europe as a means of preventing rickets in children.

In the 1920s, irradiation of yeast was found to promote antirachitic activity. Ergosterol was identified as the sterol in yeast that had antirachitic activity when irradiated; ergosterol was called provitamin $\mathrm{D}_{2}$ and its 
irradiation product, vitamin $\mathrm{D}_{2}$. Ergosterol was added to milk, followed by ultraviolet irradiation to enhance the antirachitic activity of the milk. Windaus and colleagues developed an analog of ergosterol that had a side chain for cholesterol which had similar antirachitic activity as irradiated ergosterol. This new provitamin D was called 7-dehydrocholesterol and its resulting vitamin $\mathrm{D}$ was called vitamin $\mathrm{D}_{3} \cdot{ }^{1,2}$

Once vitamin $\mathrm{D}_{2}$ was easily made from ergosterol, it was added to milk directly and replaced the irradiation process. Within a few years after this process of fortifying milk with vitamin D was implemented in the 1930s, rickets was eradicated as a health problem. ${ }^{5}$ This was implemented in the 1930s along with widespread use of cod liver oil, within a few years, eradicating rickets as a public health problem. ${ }^{4}$ Vitamin D fortification became so popular that it was added to custard, hotdogs and even beer in the US.

In the early 1950s, in Great Britain, an outbreak of hypercalcemia in infants was thought to be due to the over fortification of milk with vitamin D. Although this was never proven, the resulting hysteria about children becoming intoxicated with vitamin $\mathrm{D}$ from milk prompted Great Britain to ban vitamin $\mathrm{D}$ fortification of most foods, and all other European countries soon followed suit. Vitamin D fortification of margarine was eventually introduced in Europe as a way of preventing vitamin D deficiency in children and today many breakfast cereals are also fortified with vitamin D in most European countries. Finland and Sweden began to fortify their milk with vitamin D in the 1990s, but overall, fortification is not widely practiced in Europe.

\section{BIOLOGIC FUNCTIONS OF VITAMIN D FOR BONE HEALTH}

During exposure to sunlight, 7-dehydrocholesterol in the epidermis and dermis absorb ultraviolet $\mathrm{B}$ radiation resulting in the production of previtamin $\mathrm{D}_{3}$. Previtamin $\mathrm{D}_{3}$ is rapidly converted by thermally induced rearrangement of the double bonds to form vitamin $\mathrm{D}_{3}$. Vitamin $\mathrm{D}_{3}$ enters the circulation and is bound to the vitamin $\mathrm{D}$ binding protein. It enters the liver where it is converted to 25-hydroxyvitamin $\mathrm{D}_{3}\left[25(\mathrm{OH}) \mathrm{D}_{3}\right]$ (Figure 1). ${ }^{6}$ Both vitamin $\mathrm{D}_{2}$ and vitamin $\mathrm{D}_{3}$ are converted to their respective 25-hydroxymetabolites, and are known collectively as total 25 -hydroxyvitamin $\mathrm{D}[25(\mathrm{OH}) \mathrm{D}] .25(\mathrm{OH}) \mathrm{D}$ is the major circulating form of vitamin $\mathrm{D}$ that is measured by clinical laboratories to determine a patient's vitamin D status. ${ }^{6} 25(\mathrm{OH}) \mathrm{D}$ is biologically inactive and is transported on the vitamin D binding protein to the kidneys where it is 
converted to 1,25 -dihydroxyvitamin $\mathrm{D}\left[1,25(\mathrm{OH})_{2} \mathrm{D}\right]$ which is considered to be the biologically active form of vitamin D. It is responsible for regulating calcium and bone metabolism by enhancing intestinal calcium absorption and mobilizing calcium from the skeleton (Figure 1). ${ }^{6}$

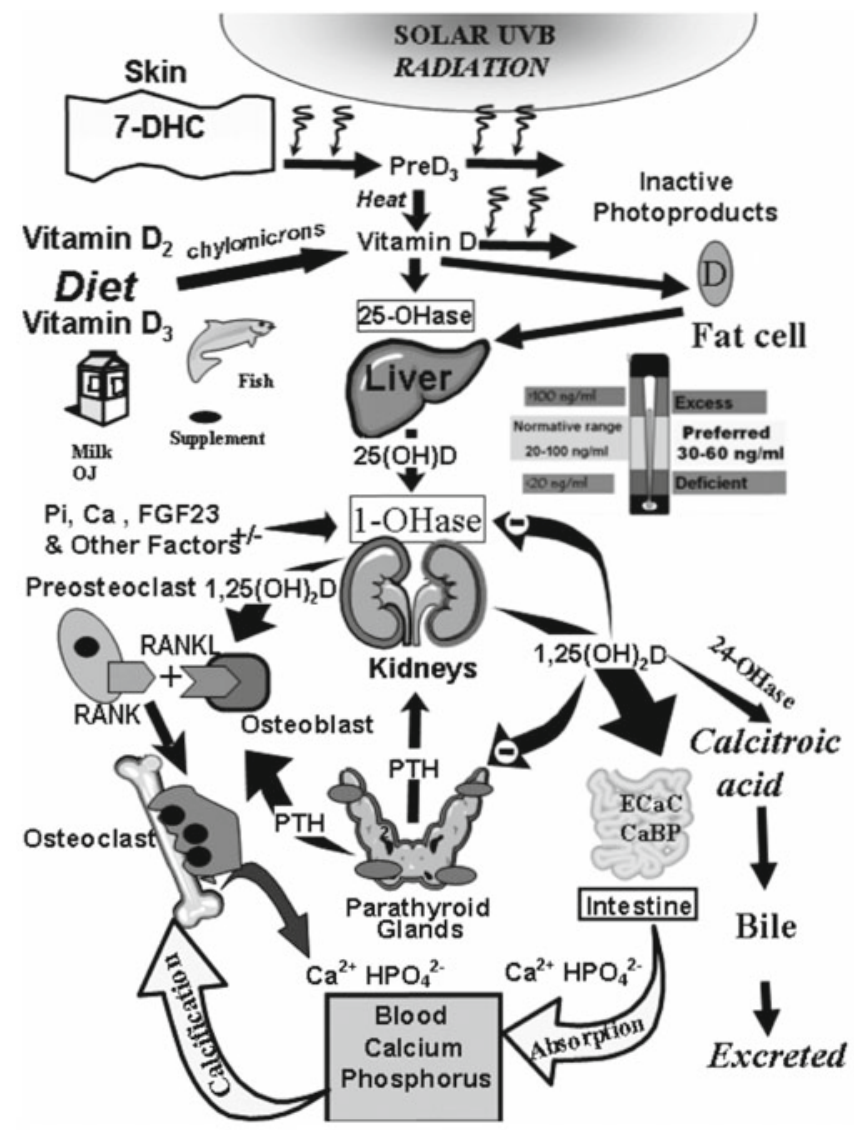

Fig. 1. Schematic representation of the synthesis and metabolism of vitamin D for regulating calcium, phosphorus and bone metabolism.

Note: During exposure to sunlight, 7-dehydrocholesterol in the skin is converted to previtamin $\mathrm{D}_{3}$. Pre $\mathrm{D}_{3}$ immediately converts by a heat dependent process to vitamin $\mathrm{D}_{3}$. Excessive exposure to sunlight degrades previtamin $\mathrm{D}_{3}$ and vitamin $\mathrm{D}_{3}$ into inactive photoproducts. Vitamin $\mathrm{D}_{2}$ and vitamin $\mathrm{D}_{3}$ from dietary sources is incorporated into chylomicrons, transported by the lymphatic system into the venous circulation. Vitamin D (D represents $\mathrm{D}_{2}$ or $\mathrm{D}_{3}$ ) made in the skin or ingested in the diet can be stored in and then released from fat cells. Vitamin D in the circulation is bound to the vitamin D binding protein which transports it to the liver where vitamin D is converted by the vitamin D-25-hydroxylase to 
25-hydroxyvitamin $\mathrm{D}[25(\mathrm{OH}) \mathrm{D}]$. This is the major circulating form of vitamin $\mathrm{D}$ that is used by clinicians to measure vitamin $\mathrm{D}$ status (although most reference laboratories report the normal range to be $20-100 \mathrm{ng} / \mathrm{ml}$, the preferred healthful range is $30-60 \mathrm{ng} / \mathrm{ml}$ ). It is biologically inactive and must be converted in the kidneys by the 25 -hydroxyvitamin $\mathrm{D}-1 \alpha$ hydroxylase (1-OHase) to its biologically active form 1,25-dihydroxyvitamin $\mathrm{D}\left[1,25(\mathrm{OH})_{2} \mathrm{D}\right]$. Serum phosphorus, calcium fibroblast growth factors (FGF-23) and other factors can either increase $(+)$ or decrease $(-)$ the renal production of $1,25(\mathrm{OH})_{2} \mathrm{D} \cdot 1,25(\mathrm{OH})_{2} \mathrm{D}$ feedback regulates its own synthesis and decreases the synthesis and secretion of parathyroid hormone $(\mathrm{PTH})$ in the parathyroid glands. $1,25(\mathrm{OH})_{2} \mathrm{D}$ increases the expression of the 25-hydroxyvitamin $\mathrm{D}$-24-hydroxylase (24-OHase) to catabolize $1,25(\mathrm{OH})_{2} \mathrm{D}$ to the water soluble biologically inactive calcitroic acid which is excreted in the bile. $1,25(\mathrm{OH})_{2} \mathrm{D}$ enhances intestinal calcium absorption in the small intestine by stimulating the expression of the epithelial calcium channel $(\mathrm{ECaC})$ and the calbindin $9 \mathrm{~K}$ (calcium binding protein; $\mathrm{CaBP}$ ). $1,25(\mathrm{OH})_{2} \mathrm{D}$ is recognized by its receptor in osteoblasts causing an increase in the expression of receptor activator of NFKB ligand (RANKL). Its receptor RANK on the preosteoclast binds RANKL which induces the preosteoclast to become a mature osteoclast. The mature osteoclast removes calcium and phosphorus from the bone to maintain blood calcium and phosphorus levels. Adequate calcium and phosphorus levels promote the mineralization of the skeleton. ${ }^{6}$

Source: Reference ${ }^{6}$ Holick copyright 2007. Reproduced with permission.

Patients who are vitamin D deficient absorb only about 10 to 15 percent of their dietary calcium and 60 percent of their dietary phosphorus. When vitamin $\mathrm{D}$ deficiency is corrected, intestinal calcium absorption increases to about 30-40 percent and phosphorus absorption is increased to about 80 percent. Vitamin D's major function for bone health, therefore, is to maintain an adequate calcium-phosphorus product which results in the mineralization of osteoid laid down by osteoblasts.

\section{CONSEQUENCES OF VITAMIN D DEFICIENCY ON CALCIUM AND BONE METABOLISM}

Vitamin D deficiency causes a decrease in the efficiency of intestinal calcium absorption and results in a decrease in ionized calcium. The calcium sensor in the parathyroid glands immediately recognizes the decrease causing the parathyroid glands to increase the production and secretion of parathyroid hormone (PTH) (Figure 1) ${ }^{6,7}$ PTH maintains serum calcium levels by increasing tubular reabsorption of calcium in the kidneys. Through its receptor on osteoblasts, PTH stimulates the formation of osteoclasts, which in turn dissolves the bone matrix and mineral to release the calcium into the extracellular space (Figure 1). ${ }^{6}$ This process, known as secondary hyperparathyroidism, can precipitate and exacerbate both osteopenia and osteoporosis, increasing risk of fracture ${ }^{6,8} \mathrm{PTH}$ also causes phosphorus loss in the urine resulting in a low-normal serum phosphorus level. 
The net result is in an inadequate calcium-phosphate product necessary for the mineralization of the collagen matrix leading to osteomalacia. ${ }^{1,6} \mathrm{In}$ children, poorly mineralized matrix and abnormal chondrocyte maturation leads to the classic skeletal deformities of rickets including the inward or outward bowing of the legs, widened epiphyseal plates at the end of the long bones and costochondral junctions, frontal bossing of the skull, craniotabes and a delay in tooth eruption. ${ }^{1,2}$ In adults, there is enough mineral in the long bones and the epiphyseal plates are closed; thus, there are no obvious skeletal deformities. However, the unmineralized matrix underneath the periosteal membrane that is heavily innervated with sensory fibers is hydrated and pushed upwards, often being perceived by the patient as throbbing aching bone pain. These patients are often misdiagnosed as having fibromyalgia, chronic fatigue syndrome or arthritis. Neither a skeletal x-ray nor a bone density scan can distinguish between osteomalacia, osteopenia and osteoporosis. They look the same i.e., decreased bone mineral (calcium) content that can increase risk of fractures. ${ }^{6,8}$

\section{NON-CALCEMIC FUNCTIONS OF VITAMIN D}

The association of living at upper (and lower) latitudes (i.e., above or below the $35^{\text {th }}$ parallels of latitude) with increased risk of dying from cancer, type 1 diabetes, multiple sclerosis and hypertension is well documented. ${ }^{6,89} \mathrm{It}$ has been assumed that living beyond the temperate zone at higher latitudes increases risk of vitamin D deficiency because of decreased sun exposure on account of longer winters and the angle of sun, which is such that there is decreased ultraviolet $\mathrm{B}$ radiation. It is also recognized that every tissue and cell in the body including immune, brain, colon, prostate, and breast cells, among many others, have a vitamin D receptor (VDR) ${ }^{6-10}$ Studies have revealed that upwards of 2000 genes are either directly or indirectly regulated by $1,25(\mathrm{OH})_{2} \mathrm{D} .{ }^{6,11}$ Initially, it was thought that increasing your vitamin $\mathrm{D}$ intake or exposure to sunlight raised your blood levels of $25(\mathrm{OH})$ $\mathrm{D}$, which resulted in increased blood levels of $1,25(\mathrm{OH})_{2} \mathrm{D}$, which in turn could interact with a wide variety of genes in a multitude of cells and organs to maintain cells and organ health, thereby reducing risk of chronic diseases. However, the conundrum was that the kidneys only produced a finite amount of $1,25(\mathrm{OH})_{2} \mathrm{D}$ that was tightly regulated by the serum calcium, phosphorus and PTH levels in the circulation. The realization that many tissues and cells in the body including among others the skin, breast, prostate, brain, and activated macrophages have an enzymatic process that is identical to the kidneys converting $25(\mathrm{OH}) \mathrm{D}$ to $1,25(\mathrm{OH})_{2} \mathrm{D}$, provided a 
new insight as to how vitamin $\mathrm{D}$ could have all of the other health benefits not related to calcium and bone metabolism Figure 2. ${ }^{6,12}$

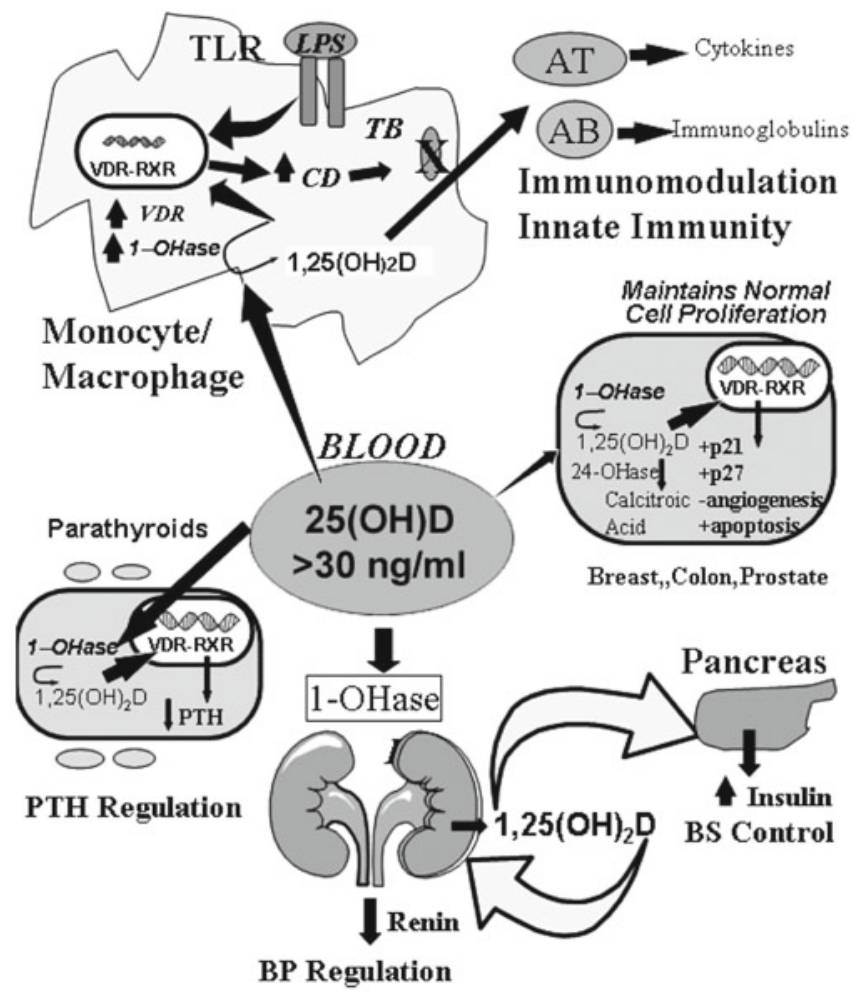

Fig. 2. Metabolism of 25-hydroxyvitamin D [25(OH)D] to 1,25 dihydroxyvitamin D $1,25(\mathrm{OH})_{2} \mathrm{D}$ for non-skeletal functions.

Note: When a monocyte/macrophage is stimulated through its toll-like receptor 2/1 (TLR2/1) by an infective agent such as Mycobacterium tuberculosis (TB), or its lipopolysaccharide (LPS) the signal upregulates the expression of vitamin D receptor (VDR) and the 25-hydroxyvitamin D-1-hydroxylase (1-OHase). 25(OH)D levels $>30 \mathrm{ng} / \mathrm{ml}$ provides adequate substrate for the $1-\mathrm{OH} a s e$ to convert it to $1,25(\mathrm{OH})_{2} \mathrm{D} \cdot 1,25(\mathrm{OH})_{2} \mathrm{D}$ returns to the nucleus where it increases the expression of cathelicidin (CD) which is a peptide capable of promoting innate immunity and inducing the destruction of infective agents such as TB. It is also likely that the $1,25(\mathrm{OH})_{2} \mathrm{D}$ produced in the monocytes/macrophage is released to act locally on activated T (AT) and activated B (AB) lymphocytes which regulate cytokine and immunoglobulin synthesis respectively. When $25(\mathrm{OH}) \mathrm{D}$ levels are $\approx 30 \mathrm{ng} / \mathrm{ml}$, it reduces risk of many common cancers. It is believed that the local production of $1,25(\mathrm{OH})_{2} \mathrm{D}$ in the breast, colon, prostate, and other cells regulates a variety of genes that control proliferation including p21 and p27 as well as genes that inhibit angiogenesis and induced apoptosis. Once $1,25(\mathrm{OH})_{2} \mathrm{D}$ completes the task of maintaining normal cellular proliferation and differentiation, 
it induces the 25-hydroxyvitamin D-24-hydroxylase (24-OHase). The 24-OHase enhances the metabolism of $1,25(\mathrm{OH})_{2} \mathrm{D}$ to calcitroic acid which is biologically inert. Thus, the local production of $1,25(\mathrm{OH})_{2} \mathrm{D}$ does not enter the circulation and has no influence on calcium metabolism. The parathyroid glands have 1-OHase activity and the local production of $1,25(\mathrm{OH})_{2} \mathrm{D}$ inhibits the expression and synthesis of PTH. The production of $1,25(\mathrm{OH})_{2} \mathrm{D}$ in the kidney enters the circulation and is able to down regulate renin production in the kidney and to stimulate insulin secretion in the $\beta$-islet cells of the pancreas.

Source: Reference ${ }^{6}$ Holick copyright 2007. Reproduced with permission.

\section{THE VITAMIN D DEFICIENCY PANDEMIC}

In the 1940s, $100 \mathrm{IU}$ of vitamin D/day was considered sufficient to prevent overt skeletal deformities associated with rickets. ${ }^{6}$ Regulatory agencies in the US and Europe later increased the dose two-fold and recommended that $200 \mathrm{IU}$ of vitamin D/day be required to satisfy the requirement for children. It was assumed that the same was true for adults. Since rickets is not commonly seen, physicians, regulatory and healthcare agencies and the general public concluded that vitamin D deficiency was conquered. In Canada, following the end of mandatory regulations after World War II, when routine vitamin $\mathrm{D}$ fortification of milk was stopped in many dairies, cases of rickets were reported as increased in admissions to Montreal hospitals, leading to reintroduction of mandatory milk fortification with vitamin D by federal regulation in 1979. In the 1950s, an outbreak of hypercalcemia in Great Britain was attributed to vitamin D intoxication and led to laws forbidding the fortification of dairy products and most food products with vitamin $\mathrm{D}$, except cereals and margarine.

In the 1970s, clinical assays were developed for $25(\mathrm{OH}) \mathrm{D}$ in the serum. To determine the normal range for the assay, blood was collected from healthy adults who were presumed to be vitamin D sufficient and the mean \pm two standard deviations was used as the normal range $(10-55 \mathrm{ng} / \mathrm{mL})$ at that time. In 1998, healthy adults with a blood level of 25(OH)D between 11 and $25 \mathrm{ng} / \mathrm{mL}$ were considered to be vitamin D sufficient. When they received 50,000 IU of vitamin $\mathrm{D}_{2}$ weekly for eight weeks, there was a substantial decrease in their PTH levels. On average, there was a 35 percent decrease in PTH levels in the adults who had blood levels less than $20 \mathrm{ng} /$ $\mathrm{mL}$. Thus it was concluded that vitamin D deficiency should be defined as a $25(\mathrm{OH}) \mathrm{D}<20 \mathrm{ng} / \mathrm{mL} \cdot{ }^{13}$ It was also observed that PTH levels began to plateau when $25(\mathrm{OH}) \mathrm{D}$ levels were between 30 and $40 \mathrm{ng} / \mathrm{mL} \cdot{ }^{14}$ Postmenopausal women who had their blood level of $25(\mathrm{OH}) \mathrm{D}$ increased from 20 to $30 \mathrm{ng} / \mathrm{ml}$ had a 65 percent increase on average in their efficiency of intestinal calcium absorption. ${ }^{15}$ Based on all of these data, it has been 
suggested that vitamin D deficiency be defined as $25(\mathrm{OH}) \mathrm{D}<20 \mathrm{ng} / \mathrm{mL}$ and vitamin $\mathrm{D}$ insufficiency as 21-29 $\mathrm{ng} / \mathrm{mL}$ (Figure 1) ${ }^{6,8}$

Based on the new definitions for vitamin D deficiency and insufficiency, it has been estimated that more than one billion people worldwide are either vitamin $\mathrm{D}$ deficient or insufficient. ${ }^{6,8,9}$ A multitude of studies have reported that 50-100 percent of the elderly men and women in the US and Europe are vitamin D deficient. ${ }^{6}$ Children, pregnant and lactating women, and young adults are at equally high risk. At the time of birth, 76 percent of mothers and 81 percent of newborns were vitamin D deficient even though the women were ingesting $600 \mathrm{IU}$ of vitamin D/day during pregnancy. ${ }^{6} \mathrm{It}$ has been estimated that more than 50 million teenagers in the US are either vitamin D deficient or insufficient. ${ }^{16}$ Fifty percent of children ages 1 to 5 and 70 percent of children 6 to 11 years of age were found to be vitamin D deficient or insufficient in the US. ${ }^{17}$ Thirty to more than 50 percent of children living in India, China and Saudi Arabia were vitamin D deficient. ${ }^{6}$ Thirty-two percent of healthy physicians and medical residents at a Boston hospital who took a multivitamin containing $400 \mathrm{IU}$ of vitamin D/day and drank a glass of vitamin D fortified milk/day were found to be vitamin D deficient. In Europe, very few foods are fortified with vitamin D and therefore both children and adults are at high risk for this vitamin deficiency. In the US, a 20 percent decline was reported in the serum 25(OH)D levels as measured by the national database NHANES III between 1994 and 2004. The major causes were obesity, lifestyle changes, decreased milk consumption and increased use of sun protection. ${ }^{18}$

Reports of Vitamin D deficiency from countries as diverse as Great Britain ${ }^{19}$ Austria, ${ }^{20}$ Germany, ${ }^{21}$ Finland,${ }^{22}$ New Zealand ${ }^{23}$ and India ${ }^{24}$ indicate the scope of the pandemic. Even sunny Australia reports 30 to 50 percent of children and adults as being vitamin $\mathrm{D}$ deficient. ${ }^{6}$ The age groups included in studies of these countries include young adults and the elderly with wide variation by country of residence. ${ }^{25}$ Even where vitamin $\mathrm{D}$ fortification of milk has been in place for many decades, as in the US and Canada, there are still major deficiencies related to season, latitude of residence, age, gender and social conditions. ${ }^{26}$ Adequate exposure to summer sunlight is the essential means to ample supply, but oral intake augmented by both fortification and supplementation is necessary to maintain baseline stores.

\section{CONSEQUENCES OF VITAMIN D DEFICIENCY ON HEALTH}

The skeletal consequences of vitamin D deficiency on bone health include osteoporosis and increased risk for fractures, especially of the hip, vertebrae 
and forearm with serious impact on quality of life and survival. ${ }^{6,8}$ What is less appreciated is that vitamin D deficiency causes muscle weakness, increasing risk of swaying and falling, thus further increasing risk of fracture in the frail elderly. ${ }^{6,8}$

Vitamin D deficiency has been associated with increased risk for cancer, including that of the breast, prostate, colon and ovaries. ${ }^{6-10}$ Women who had a blood level of $25(\mathrm{OH}) \mathrm{D} \sim 48 \mathrm{ng} / \mathrm{mL}$ reduced their risk of developing breast cancer by 50 percent. ${ }^{27}$ This is consistent with the observation that women who had the most sun exposure as teenagers and young adults reduced their risk of developing breast cancer later in life by more than 60 percent. ${ }^{28} \mathrm{~A}$ retrospective analysis of postmenopausal women receiving $1500 \mathrm{mg}$ of calcium and $1100 \mathrm{IU}$ of vitamin $\mathrm{D}$ a day revealed a decrease of more than 60 percent in the development of all cancers compared to women who either took calcium without vitamin D or a placebo. ${ }^{29}$ The International Agency for Research on Cancer 2008 review of evidence of vitamin D and cancer show evidence for an increased risk of colorectal cancer and colorectal adenoma with low serum 25-hydroxyvitamin D levels. ${ }^{30}$

Osteoporosis and vitamin D deficiency have also been linked with increased risk of many chronic diseases including: heart disease, type 2 diabetes, autoimmune and infectious diseases, asthma and other wheezing disorders. It is well documented that living at upper and lower latitudes increases risk for multiple sclerosis and type 1 diabetes. Women who had the highest blood levels of 25(OH)D had a 42 percent reduced risk of developing multiple sclerosis as compared to women with the lowest blood levels. ${ }^{6,8}$ Similarly, women who had the highest intake of vitamin D reduced their risk of developing rheumatoid arthritis by more than 40 percent. $^{6}$ Children in Finland who received $2000 \mathrm{IU}$ of vitamin D/day during their first year of life and followed for 31 years were found to have a 78 percent reduced risk of developing type 1 diabetes. ${ }^{31}$

Vitamin D deficiency has been associated with a 50 percent increased risk of having a myocardial infarction. ${ }^{32}$ Hypertension, congestive heart failure and peripheral vascular disease have been associated with vitamin D deficiency. ${ }^{6}$ Vascular smooth muscle, and cardiomyocytes have a vitamin D receptor, and it has been estimated that up to 200 genes related to cardiovascular health may be directly or indirectly influenced by $1,25(\mathrm{OH})_{2} \mathrm{D}$. Furthermore, renin production is down-regulated by $1,25(\mathrm{OH})_{2} \mathrm{D}{ }^{6}$

Activated macrophages can convert $25(\mathrm{OH}) \mathrm{D}$ to $1,25(\mathrm{OH})_{2} \mathrm{D}$. When the macrophage produces $1,25(\mathrm{OH})_{2} \mathrm{D}$, it instructs the cell to produce cathelicidin which is a member of the defensin protein family whose purpose is to kill infective agents such as tuberculosis. ${ }^{6,33}$ This led to the suggestion 
that the reason why upper respiratory tract infections and influenza are most common during the winter is that that is the time when the $25(\mathrm{OH}) \mathrm{D}$ levels are at their lowest. It has been reported that adults in the United States with the highest blood levels of 25(OH)D had the lowest risk for developing upper respiratory tract infections compared to adults with the lowest blood levels. ${ }^{34} \mathrm{~A}$ study in postmenopausal women who received $2000 \mathrm{IU}$ of vitamin D/day indicated a risk of upper respiratory tract infections reduced by 90 percent in one year. ${ }^{6}$

People tend to reduce their sun exposure when given advice to avoid the sun to prevent risk of skin cancers. Adults work mainly indoors, and children and adolescents are spending increasing amounts of time indoors playing on computers instead of being out of doors. The use of sunscreens promoted by advertising such as the "slip slap slop" message in Australia has resulted in a marked increase in vitamin D deficiency in children and adults. Eighty seven percent of Australian dermatologists had a deficient blood level of $25(\mathrm{OH}) \mathrm{D}<20 \mathrm{ng} / \mathrm{mL}$ at the end of the summer. ${ }^{35}$

\section{PREVENTION AND TREATMENT FOR VITAMIN D DEFICIENCY AND INSUFFICIENCY}

There have been two reports suggesting that vitamin $\mathrm{D}_{2}$ is less effective than vitamin $\mathrm{D}_{3}$ in maintaining vitamin $\mathrm{D}$ status, and that vitamin $\mathrm{D}_{2}$ increases the destruction of $25(\mathrm{OH}) \mathrm{D}_{3}$. However, there are several other studies that have reported that vitamin $\mathrm{D}_{2}$ is as effective as vitamin $\mathrm{D}_{3}$ in maintaining vitamin D status in both children and adults. ${ }^{6,36,37}$ In children, $2000 \mathrm{IU}$ of vitamin $\mathrm{D}_{2}$ /day was as effective as giving $2000 \mathrm{IU}$ of vitamin $\mathrm{D}_{3} /$ day in maintaining their serum $25(\mathrm{OH}) \mathrm{D}$ levels. ${ }^{37}$ Healthy adults who received $1000 \mathrm{IU}$ of vitamin $\mathrm{D}_{2}$ or $1000 \mathrm{IU}$ of vitamin $\mathrm{D}_{3}$ or $500 \mathrm{IU}$ of vitamin $\mathrm{D}_{2}+500 \mathrm{IU}$ of vitamin $\mathrm{D}_{3}$ were able to raise their blood levels of 25(OH)D by $10 \mathrm{ng} / \mathrm{mL}$.

It has been estimated that for every $100 \mathrm{IU}$ of vitamin D/day that is taken, the blood level of $25(\mathrm{OH}) \mathrm{D}$ is increased by $1 \mathrm{ng} / \mathrm{mL}(2.5 \mathrm{nmol} / \mathrm{L}){ }^{6,36}$ Healthy adults receiving $1000 \mathrm{IU}$ of vitamin D a day for three months during the winter in Boston and who had an average serum 25(OH)D of 18 $\mathrm{ng} / \mathrm{mL}$ raised their blood level to $28 \mathrm{ng} / \mathrm{mL}$ and thus did not achieve vitamin $\mathrm{D}$ sufficiency. ${ }^{36}$ To treat vitamin $\mathrm{D}$ deficiency, pharmacologic doses of vitamin D are often required. A simple strategy is to fill up the empty vitamin $\mathrm{D}$ tank by giving $50,000 \mathrm{IU}$ of vitamin $\mathrm{D}_{2}$ once a week for eight weeks. This is equivalent to taking $6000 \mathrm{IU}$ of vitamin $\mathrm{D}$ a day. However, to prevent a recurrence of vitamin D deficiency, an effective strategy is to 
then give 50,000 IU of vitamin $\mathrm{D}_{2}$ once every two weeks indefinitely. Recently, after keeping study subjects on this medical regimen for six years, it was reported that men and women were able to maintain a blood level of $25(\mathrm{OH}) \mathrm{D}>30 \mathrm{ng} / \mathrm{mL}$ (range $\sim 40-60 \mathrm{ng} / \mathrm{mL}$ ). ${ }^{38}$ The serum calcium remained normal throughout the study and no toxicities or increased incidences of kidney stones were reported.

There are now several reports of both children and adults receiving 2000 IU of vitamin D a day for up to a year with the result of maintaining their blood levels at $25(\mathrm{OH}) \mathrm{D}>30 \mathrm{ng} / \mathrm{mL}$. In one study, prepubertal and teenage girls who received $2000 \mathrm{IU}$ of vitamin $\mathrm{D}_{3}$ a day for one year showed improvement in bone mineral density ${ }^{39}$ It has been estimated that adults who received at least $800 \mathrm{IU}$ of vitamin $\mathrm{D}$ a day can reduce their risk of fracture by more than 50 percent and risk of falling by as much as 72 percent. ${ }^{40,41}$

\section{VITAMIN D TOXICITY}

There has been great concern about increasing vitamin D intake for children and adults because of potential vitamin D toxicity which causes hypercalcemia, hyperphosphatemia, nephrocalcinosis, and soft tissue calcification, all of which can contribute to increased risk of death. Studies have shown that adults can take up to 10,000 IU of vitamin D a day for at least five months without altering their serum calcium or urinary calcium output. ${ }^{42}$ One method for preventing rickets in neonates in the inner cities of Europe was to give a single 200,000 IU injection of vitamin D. ${ }^{1,6}$ Studies in children and adults receiving $2000 \mathrm{IU}$ of vitamin D a day have not reported any toxicity.

Vitamin D intoxication is one of the rarest medical conditions that may be caused either by intentional or inadvertent exposure to excessively high amounts of vitamin $\mathrm{D}$ attained by ingesting an average of more than 10,000 IU of vitamin D a day for more than six months. In one case report, a man took 2 teaspoons a day of a product thinking it contained $1000 \mathrm{IU}$ of vitamin D per teaspoon for more than six months. When he presented with vitamin D intoxication, an analysis of his vitamin $\mathrm{D}$ preparation was made and found to be undiluted and containing 1 million IU of vitamin D in 2 teaspoons. ${ }^{6}$

\section{CONCLUSION AND RECOMMENDATIONS}

Vitamin D deficiency and insufficiency is pandemic and is seen in essentially every country in the world. There are many causes (Figure 3), but lack of 
awareness of the importance of this deficiency is crucial in individual and public health. Oily fish, cod liver oil and mushrooms exposed to sunlight or ultraviolet radiation are the only natural sources. The need for fortifying basic foods with vitamin $\mathrm{D}$ is now ever more important since excess sun exposure, a major source of this vital hormone/nutrient, is related to skin cancers and lifestyle changes reduce outdoor exposure for children and many other age groups. Since very few foods are fortified with vitamin D and there is typically only $100 \mathrm{IU}$ of vitamin D in a serving, natural foods provide only a small portion of what is required to satisfy either a child's or adult's vitamin D requirement. The worldwide concern about sun exposure and skin cancer has also exacerbated the problem. ${ }^{6,835}$

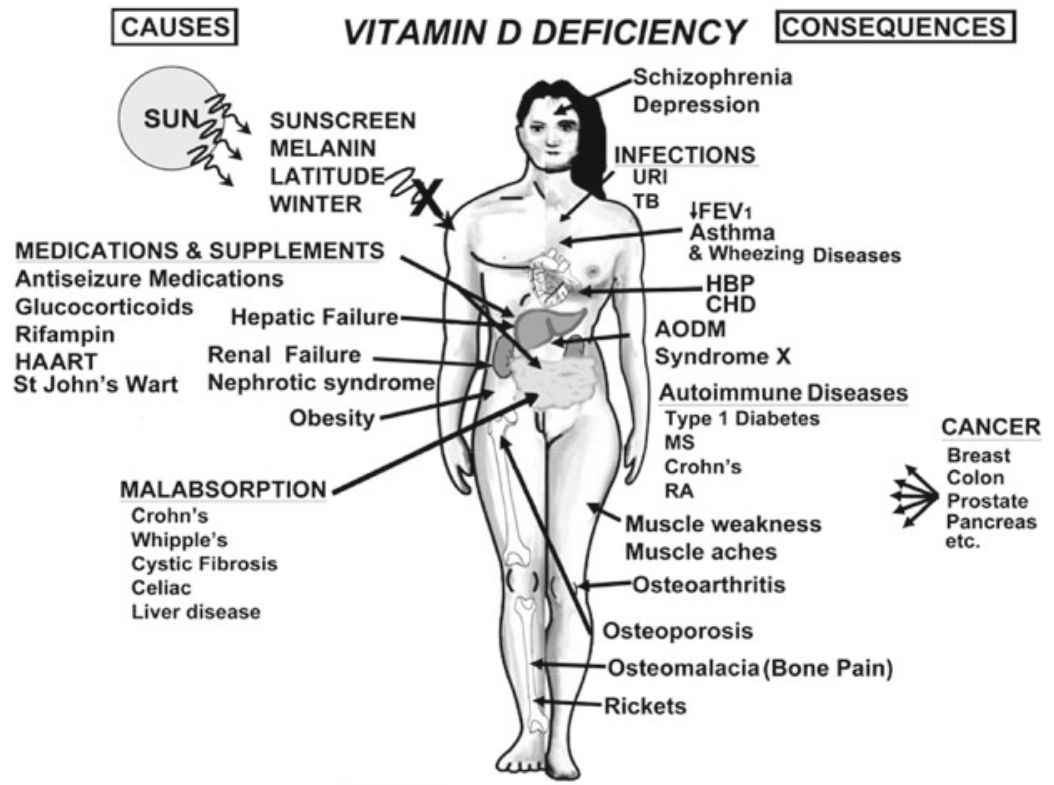

Fig. 2. A Schematic Representation of the Major Causes for Vitamin D Deficiency and Potential Health Consequences.

Source: Reference ${ }^{6}$ Holick copyright 2007 . Reproduced with permission.

The vitamin D deficiency pandemic increases the entire world's population risk of the most serious chronic illnesses including deadly cancers, type 2 diabetes, heart disease, stroke, autoimmune diseases, asthma and infectious diseases (Figure 3). There is no drawback to increasing your vitamin $\mathrm{D}$ intake unless you have a granulomatous disorder. Thus there 
needs to be increased awareness on the part of the medical community and public about the insidious consequences of vitamin D deficiency.

In 2008, the American Academy of Pediatrics increased its recommended daily supplements recommendation from 200 to $400 \mathrm{IU} /$ day for infants, children and adolescents. ${ }^{43,44}$ Recommended daily intake for elderly adults was also increased to $1,000 \mathrm{IU} /$ day. New recommendations continue to emerge, substantially increasing the adequate intakes for children and adults as well as what is considered to be the safe upper limit of intake. Recommendations for sensible daily sun exposure and adequate vitamin D supplementation are both in a state of flux. Food fortification policies are needed to assure a basic level of vitamin D intake. People in long-term care and custodial situations should be given daily supplements of vitamin D perhaps in the form of multivitamins to ensure adequacy of essential elements, especially vitamin D.

Public policies to ensure adequate vitamin $\mathrm{D}$ intake in public health nutrition are vital for all countries including the industrialized countries as well as former Soviet countries in transition and developing countries. Migrant population groups with dark skin migrating to northern latitudes and especially those who cover themselves for religious reasons are at high risk for vitamin $\mathrm{D}$ deficiency, as are their breastfed babies unless adequately supplemented with vitamin D. Teenagers and young adults are less exposed to the sun due to work and lifestyle changes. Precautions regarding overexposure to the sun are justified, but moderate sun exposure during midday is especially important for older adults.

Vitamin D deficiency is so widespread that a combination of food fortification for the total population and individual screening for people in groups at risk for this important deficiency is needed. Clinical testing and population surveys of $25(\mathrm{OH}) \mathrm{D}$ levels should be integral to population health monitoring. Awareness by the general public, healthcare providers and health insurance systems of the importance of vitamin D adequacy could have a dramatic impact on the health and welfare of all children and adults.

All countries in Europe and globally should mandate fortification of milk, (including milk formulas, powders and evaporated milk), soft milk products (yoghurts, cottage cheeses and others) as a key vehicle for prevention of deficiency of vitamin $\mathrm{D}$, including in sunny countries. International agencies such as the World Health Organization, UNICEF and the major donors should promote fortification as an essential element of the New Public Health. Further, all health systems should incorporate routine clinical testing of $25(\mathrm{OH}) \mathrm{D}$ levels for those at risk and vitamin $\mathrm{D}$ supplementation as routine preventive measures among age groups as 
discussed above. Recognition of the pandemic of vitamin D deficiency obliges governments to lead in regulation of mandatory fortification and monitoring of compliance by industry.

Conflicts of interest: This work was supported in part by the UV Foundation.

\section{REFERENCES}

1. Holick MF. Resurrection of vitamin D deficiency and rickets. J Clin Invest. 2006; 116:2062-72.

2. Rajakumar K, Greenspan SL, Thomas SB, Holick MF. Solar ultraviolet radiation and vitamin D: a historical perspective. Am J Public Health. 2007;97:174654.

3. Sniadecki J. Jerdrzej Sniadecki (1768-1838) on the cure of rickets. (1840) Cited by W. Mozolowski. Nature. 1939;143:121-124.

4. Huldschinsky K. The ultra-violet light treatment of rickets. New Jersey: Alpine Press; 1928. p.3-19.

5. Centers for Disease Control. Achievements in public health, 1900-1999: Safer and healthier foods. MMWR Morb Mortal Wkly Rep. 1999:48:905-13.

6. Holick MF. Vitamin D deficiency. N Engl J Med. 2007;357:266-8.

7. Dusso AS, Brown AJ, Slatopolsky E. Vitamin D. Am J Physiol Renal Physiol. 2005;289:F8-28.

8. Bischoff-Ferrari HA, Giovannucci E, Willett WC, Dietrich T, Dawson-Hughes B. Estimation of optimal serum concentrations of 25-hydroxyvitamin D for multiple health outcomes. Am J Clin Nutr. 2006;84:18-28.

9. Moan J, Porojnicu AC, Dahlback A, Setlow RB. Addressing the health benefits and risks, involving vitamin D or skin cancer, of increased sun exposure. Proc Natl Acad Sci U.S.A. 2008;105:668-73.

10. Grant WB. A critical review of vitamin D and cancer. A report of the IARC Working Group on Vitamin D. Dermatoendocrinol 2009;1:25-33.

11. Nagpal S, Na S, Rathnachalam R. Noncalcemic actions of vitamin D receptor ligands. Endocr Rev. 2005;26:662-87.

12. Bikle D. Nonclassic actions of vitamin D. J Clin Endocrinol Metab 2009;94:2634.

13. Malabanan A, Veronikis IE, Holick MF. Redefining vitamin D insufficiency. Lancet. 1998;351:805-6.

14. Chapuy MC, Preziosi P, Maamer M, Arnaud S, Galan P, Hercberg S, et al. Prevalence of vitamin D insufficiency in an adult normal population. Osteoporos Int. 1997;7:439-43.

15. Heaney RP, Dowell MS, Hale CA, Bendich A. Calcium absorption varies within the reference range for serum 25-hydroxyvitamin D. J Am Coll Nutr. 2003; 22:142-6. 
16. Rovner AJ, O'Brien KO. Hypovitaminosis D among healthy children in the United States: a review of current evidence. Arch Pediatr Adolesc Med 2008: 513-9.

17. Kumar J, Muntner P, Kaskel FJ, Hailpern, SM, Melamed ML. Prevalence and associations of 25-hydroxyvitamin D deficiency in US Children: NHANES 2001-2004. Pediatrics 2009;124:e362-70. Aug 3 [Epub ahead of print]

18. Looker AC, Pfeiffer CM, Lacher DA, Schleicher RL, Picciano MF, Yetley EA. Serum 25-hydroxyvitamin D status of the US population: 1988-1994 compared with 2000-2004. Am J Clin Nutr. 2008;88:1519-27.

19. Hyppönen E, Power C. Hypovitaminosis D in British adults at age $45 \mathrm{y}$ : nationwide cohort study of dietary and lifestyle predictors. Am J Clin Nutr. 2007 Mar;85:860-8.

20. Koenig J, Elmadfa I. Status of calcium and vitamin D of different population groups in Austria. Int J Vitam Nutr Res. 2000 Sep;70(5):214-20.

21. Hintzpeter B, Mensink GB, Thierfelder W, Müller MJ, Scheidt-Nave C. Vitamin D status and health correlates among German adults. Eur J Clin Nutr. 2008 Sep;62(9):1079-89.

22. Lamberg-Allardt CJ, Outila TA, Kärkkainen MU, Rita HJ, Valsta LM.Vitamin D deficiency and bone health in healthy adults in Finland: could this be a concern in other parts of Europe? Bone Miner Res. 2001 Nov;16:2066-73.

23. Rockell JE, Skeaff CM, Williams SM, Green TJ. Serum 25-hydroxyvitamin D concentrations of New Zealanders aged 15 years and older. Osteoporos Int. 2006;17:1382-9. Epub 2006 Jul 11.

24. Sachan A, Gupta R, Das V, Agarwal A, Awasthi PK, Bhatia V. High prevalence of vitamin D deficiency among pregnant women and their newborns in northern India. Am J Clin Nutr. 2005 May;81:1060-4.

25. McKenna MJ. Differences in vitamin D status between countries in young adults and the elderly. Am J Med. 1992 Jul;93:69-77.

26. Calvo MS, Whiting SJ, Barton CN. Vitamin D fortification in the United States and Canada: current status and data needs. In: Vitamin D and health in the 21st century: bone and beyond. Am J Clin Nutr. 2004;80:1710S-1716S.

27. Garland CF, Gorham ED, Mohr SB, Grant WB, Giovannucci EL, Lipkin M, et al. Vitamin D and prevention of breast cancer: pooled analysis. J Steroid Biochem Mol Biol. 2007;103:708-11.

28. Knight JA, Lesosky M, Barnett H, Raboud JM, Vieth R. Vitamin D and reduced risk of breast cancer: a population-based case-control study. Cancer Epidemiol Biomarkers Prev. 2007;16:422-9.

29. Lappe JM, Travers-Gustafson D, Davies KM, Recker RR, Heaney RP. Vitamin D and calcium supplementation reduces cancer risk: results of a randomized trial. Am J Clin Nutr. 2007;85:1586-91.

30. International Agency for Research on Cancer. IARC Working Group on Vitamin D. Vitamin D and cancer: a report of the IARC Working Group on Vitamin D. 2008 Lyon France. Available at URL: http://www.iarc.fr/en/publications/pdfsonline/wrk/wrk5/Report_VitD.pdf (Accessed 28 March, 2010). 
31. Hyppönen E, Läärä E, Reunanen A, Jarvelin MR, Virtanen SM. Intake of vitamin D and risk of type 1 diabetes: a birth-cohort study. Lancet. 2001;358: 1500-3.

32. Wang TJ, Pencina MJ, Booth SL, Jacques PF, Ingelsson E, Lanier K, et al. Vitamin D deficiency and risk of cardiovascular disease. Circulation. 2008; 117:503-11.

33. Liu PT, Stenger S, Li H, Wenzel L, Tan BH, Krutzik SR, et al. Toll-like receptor triggering of a vitamin D-mediated human antimicrobial response. Science 2006;311:1770-3.

34. Ginde AA, Mansbach JM, Camargo CA. Association between serum 25hydroxyvitamin D level and upper respiratory tract infection in the Third National Health and Nutrition Examination Survey. Arch Intern Med. 2009; 169:384-90.

35. Czarnecki D, Meehan CJ, Bruce F. The vitamin D status of Australian dermatologists. Clin Experimental Dermatol. 2009;34:624-5.

36. Holick MF, Biancuzzo RM, Chen TC, Klein EK, Young A, Bibuld D, et al. Vitamin D2 is as effective as vitamin D3 in maintaining circulating concentrations of 25-hydroxyvitamin D. J Clin Endocrinol Metab 2008;93: 677-81.

37. Gordon CM, Williams AL, Feldman HA, May J, Sinclair L, Vasquez A, et al. Treatment of hypovitaminosis D in infants and toddlers. J Clin Endocrinol Metab 2008;93:2716-21.

38. Pietras SM, Obayan BK, Cai MH, Holick MF. Vitamin D2 treatment for vitamin D deficiency and insufficiency for up to 6 years. Arch Intern Med 2009;169:1806-8.

39. Maalouf J, Nabulsi M, Vieth R, Kimball S, El-Rassi R, Mahfoud Z, et al. Shortand long-term safety of weekly high-dose vitamin D3 supplementation in school children. J Clin Endocrinol Metab 2008;93:2693-701.

40. Bischoff-Ferrari HA, Shao A, Dawson-Hughes B, Hathcock J, Giovannucci E, Willett WC. Benefit - risk assessment of vitamin D supplementation. Osteoporos Intl. 2009; Dec 3:(Epub ahead of print).

41. Broe KE, Chen TC, Weinberg J, Bischoff-Ferrari HA, Holick MF, Kiel DP. A higher dose of vitamin $D$ reduces the risk of falls in nursing home residents: a randomized, multiple-dose study. J Am Geriatr Soc. 2007;55:234-9.

42. Heaney RP, Davies KM, Chen TC, Holick MF, Barger-Lux MJ. Human serum 25-hydroxycholecalciferol response to extended oral dosing with cholecalciferol. Am J Clin Nutr. 2003;77:204-10.

43. Wagner CL, Greer FR; American Academy of Pediatrics Section on Breastfeeding; American Academy of Pediatrics Committee on Nutrition. Prevention of rickets and vitamin D deficiency in infants, children, and adolescents. Pediatrics. 2008 Nov;122:1142-52.

44. National Institutes of Health, Office of Dietary Supplements. US Food and Drug Administration: Dietary Supplement Fact Sheet: Vitamin D. Available from URL: http://dietary-supplements.info.nih.gov/factsheets/vitamind.asp (Updated 13 November, 2009 and accessed 24 March, 2010). 